\title{
KAJIAN MENGENAI PERUBAHAN AFILIASI PADA SISTEM ORGANISASI SOSIAL MASYARAKAT LEMATANG
}

\author{
Ari Kurniawan ${ }^{1}$, Tony Rudyansjah ${ }^{2}$ \\ Received Article: 08 Mei 2017 \\ Accepted Article: 10 J uni 2017
}

\begin{abstract}
This article discusses dynamics of social behavior which is constructed as mechanism process to exacerbate social organization. This study examines how social institutions provide significant influence to change social structures and power relations within the family institution. Lematang society are exclusive patrilineal society wherein each affiliated rules is always attracted by patrilineality. However there are some patrilineal society who actually practiced different, where the rules are affiliated to follow the matrilineality. This behavior displayed by the form of matrilocal marriage (Kampi). In this matrilocal marriage, women became a central actor in her household. This study is qualitative research with ethnographic method aimed to obtain in-depth description of social organization in Lematang society. This research showed that Kampi is one institutions to maintain lineage agnatic on families who do not have a male children. The consequence of that rule is affiliation change in patrilineal family institution. Women who conduct Kampi, would be lineage successor of her parents. Husband will be affiliated to the agnatic clan his wife, while the affiliated matrilineal descendants in his mother's lineage. This resulted in the affiliation change, the position of men being subordinated, because men lose their rights, descent, and resource access.
\end{abstract}

Keywords: Rule Affiliation, Patrilineal, Matrilineal

\section{Abstrak}

Artikel ini membahas dinamika perilaku sosial yang dibangun sebagai mekanisme proses untuk menambah peran dari organisasi sosial. Penelitian ini bertujuan melihat bagaimana lembaga sosial memberikan pengaruh yang signifikan untuk mengubah struktur sosial dan kekuasaan hubungan dalam keluarga lembaga. Masyarakat Lematang adalah masyarakat patrilineal yang eksklusif yang berafiliasi setiap aturan yang selalu tertarik oleh patrilinealitas. Walaupun demikian ada beberapa patrilineal masyarakat yang sebenarnya dilakukan yang berbeda, di mana aturan yang berafiliasi dengan mengikuti sistem kekerabatan matrilineal. Perilaku ini ditampilkan oleh bentuk perkawinan matrilokal (Kampi). Pada perkawinan matrilokal, perempuan menjadi pusat aktor dalam rumah tangganya. Studi ini menggunakan penelitian kualitatif dengan metode etnografi yang bertujuan untuk memperoleh gambaran mendalam mengenai organisasi sosial pada masyarakat Lematang. Penelitian ini menunjukkan bahwa Kampi merupakan salah satu lembaga yang masih menjaga garis keturunan dari keluarga yang tidak punya anak laki laki. Konsekuensi dari aturan ters ebut adalah terjadinya perubahan secara kelembagaan dalam lembaga keluarga patrilineal. Perempuan yang melakukan Kampi, akan merubah garis keturunannya atau pengganti dari orang tuanya. Suami akan yang berafiliasi dengan klan istrinya, ketika keturunan matrilineal akan berafiliasi melalui garis keturunan ibunya. Hal ini menunjukkan adanya perubahan kelembagaan dimana posisi laki-laki yang pernah berkuasa, karena laki-laki telah kehilangan hak hak mereka, keturunan dan akses sumber daya.

Kata Kunci: Peran Kelembagaan, Patrilineal, Matrilineal

\footnotetext{
${ }^{1}$ Penulis adalah mahasiswa pendidikan pascasarjana di Departemen Antropologi FISIP Universitas Indonesia dan bekerja pada instansi Dinas Pendidikan dan Kebudayaan Propinsi Lampung.

${ }^{2}$ Penulis adalah dosen tetap Jurusan Antropologi FISIP Universitas Indonesia, Jakarta

Kajian Mengenai Perubahan Afiliasi Pada Sistem Organisasi Sosial

89 | P a g e
} 
$\hat{M}$ endahuluan

asyarakat Lematang merupakan salah satu komunitas patrilinial yang berada di Propinsi Sumatera Sela tan. Masyarakat Lematang menganut pola perkawinan Connubium Asimetris ${ }^{3}$, yakni pola perkawinan yang dilakukan antar klan atau marga ${ }^{4}$. Sistem organisasi sosial pada masyarakat Lematang menunjukkan karak ter patrilinial, dengan pola perkawinan yang ideal adalah patrilokal. Dalam konsep patrilinial ini, setiap pertalian garis keturunan ditarik berdasarkan garis laki-laki (Haviland, 1985: 107). Sehingga, dalam praktik sosialnya, laki-laki menduduki posisi utama di berbagai ranah kehidupan. Terutama sebagai aktor sentral dalam memberikan mahar kepada perempuan. Pada perkawinan patrilokal ini, laki-laki berperan penting dalam mempersiapkan segala biaya perkawinan untuk mengambil perempuan dari kelompok patrilinial lain. Laki-laki juga akan menjadi peran yang signifikan dalam menentukan segala keputusan setelah perkawinan, termasuk pola menetap sesudah menikah, dan hakhak terkait dengan keturunan. Masyarakat Lematang termasuk salah satu masyarakat patrilinial eksklusif dimana semua terpusat pada laki-laki, mulai dari garis keturunan, perkawinan, residensi, hingga kekuasaan. Meskipun demikian, di Lematang juga terdapat beberapa kelompok masyarakat patrilinial yang justru berperilaku seperti

3 Dari Penelitian Eka Hapsari yang melihat sistem perkawinan eksogami antar komunitas di Palembang seperti kasus perkawinan antara etnis keturunan Tionghoa dengan etnis Melayu Palembang, dapat disimpulkan bahwa pola perkawinan di Lematang adalah connubium asimetris

${ }^{4}$ Lihat Van Wouden, Types of Sosial Structure in Eastern Indonesia. Terj. R. Needham (terbitan pertama 1935). The Hague: Martinus Nijhoff, 1968. Baca Juga Klan, Mitos, dan Kekuasaan; Struktur Sosial Indonesia Bagian Timur terj. Anggota IKAPI, (Jakarta: graffiti Pers, 1985), hal. 6. Lihat Juga Kuntjaraningrat, Sejarah Teori Antropologi; Struktur Elementer Pertukaran Perempuan dalam Analisis Sistem Kekerabatan Levi Straus, (Jakarta: UI Press, 1987), hal. 221-225, dan Istutiah Gunawan dalam Hierarchy and Balance; a study of Wanoaka Sosial Organization, (Canberra: Dept. of Anthropology in Association with the Comparative Austronesian Project, Research School of Pacific and Asian Studies, Australian National University, 2000), hal. 7. matrilinial. Kondisi ini dipengaruhi oleh perilaku kawin kampi.

Kawin kampi merupakan perkawi nan matrilokal dimana perempuan berperan memberikan mahar kepada laki-laki. Dengan kondisi tersebut, laki-laki beserta keturunannya akan menjadi bagian dari garis kerabat istrinya. Pada proses selanjutnya, pola matrilinial itu dipraktikkan dengan sangat terstruktur serta menjadi bagian yang signifikan dalam membentuk sistem afiliasi di Lematang. Sifat-sifat matrilinial itu berada di balik struktur patrilinial yang eksklusif sehingga tidak nampak memiliki kontribusi dalam menjelaskan organisasi sosial di Lematang, yang nampak adalah komunitas Lematang menganut sistem kekerabatan patrilinial, pola residensi patrilokal dan pola kekuasaan patriarkat $^{5}$.

Melalui perkawinan kampi ini, pola post marital residence bergeser dari patrilokal ke matrilokal. Begitu juga sistem afiliasi bergeser dari patrilinial ke matrilinial. $\mathrm{Hal}$ ini tentunya berakibat juga pada kondisi relasi-relasi kuasa akibat dari pergeseran pola afiliasi dan post marital residence tersebut.

\section{B. Kajian Teori}

istem afiliasi dalam garis kerabat
adalah seperangkat aturan yang
mengatur keanggotaan individu dalam sistem kekerabatan. Dalam hal ini sistem afiliasi di dalamnya mencakup aturan-aturan mengenai posisi, status, peran, hak dan kewajiban, pola menetap, sistem aliansi, sistem pertukaran, hubu ngan-hubungan afinitas, relasi kekuasaan, dan relasi-relasi sosial lainnya di dalam struktur sosial (Valeri, 2001:142-145).

Ember \& Ember (2007: 383) membedakan tiga tipe pokok afiliasi berkaitan dengan garis keturunan, yaitu sistem keturunan unilinial, sistem keturunan ambilinial, dan sistem kekerabatan bilateral.

\footnotetext{
${ }^{5}$ Lihat Octaviani Eka Hapsari, dalam Disonansi Kognitif pada Orang Tua yang Anaknya Melakukan Belarian, Studi Kasus Kawin Lari Antara Etnis Pribumi dengan Etnis non Pribumi di Palembang. (Jakarta: Universitas Indonesia, 2001), hal 4-5. Dinyatakan bahwa masyarakat Sumatera Selatan kecuali Semende menganut sistem kekerabatan patrilinial hal ini dibuktikan dengan pola residensi bagi perempuan yang berafiliasi dengan kerabat suami.
} 
Dua tipe pertama; unilinial descent dan ambilinial descent menurutnya didasarkan pada aturan keturunan yaitu beberapa aturan yang menghubungkan individu dengan kerabatnya mengacu kepada nenek moyang bersama. Fakta-fakta aturan sistem garis keturunan beroperasi di dalam sistem sosialnya, individu akan merasakan dan melihat bagaimana kerabat berperan penting dalam mendukung dan membantu dirinya di dalam organisasi sosialnya. Sedangkan sistem kekerabatan bilateral tidak berdasarkan pada aturan keturunan atau nenek moyang dan tidak dikonstruksi secara jelas oleh masing-masing kelompok klan. Unilinial descent sama dengan fakta bahwa seseorang berafiliasi dengan salah satu kelompok keturunan melalui garis keturunan dari salah satu nenek moyang, hanya melalui pihak laki-laki maupun perempuan saja. Unilinial descent bisa berupa patrilinial atau matrilinial saja.

Sistem ambilinial descent adalah sistem afiliasi antara individu dengan kerabat yang mengambil garis keturunan dari pihak laki-laki dan perempuan. Dengan kata lain beberapa orang di dalam kelompok sosial berafiliasi dengan group kerabat melalui ayah mereka dan juga melalui ibu mereka. Konsekuensinya kelompok keturu nan terdiri dari dua jaringan genealogis yaitu satu sisi pihak laki-laki dan pihak perempuan di sisi lain. Sistem ambilinial descent dapat disebut juga dengan sistem double descent atau double unilinial descent. Di mana seorang individu (keturunan; garis anak atau garis cucu) dalam satu klan melakukan afiliasi untuk beberapa maksud melalui sebuah kelompok kerabat matrilinial, dan beberapa maksud lain melalui kelompok patrilinial, misalnya dalam sebuah keluarga, keturunan pertama dan kedua mengikuti garis ayah, sedangkan pada keturunan ketiga dan seterusnya mengikuti garis ibu, dan kembali ke garis ayah, begitu seterusnya (Ember \& Ember, 2007: 385-386).

Sistem afiliasi bilateral dimaksudkan sebagai sistem kekerabatan yang tidak jelas, artinya tidak berdasarkan garis matrilinial, patrilinial, maupun ambilinial. Kelompok bilateral dianggap sebagai kelompok yang tidak memiliki garis keturunan atau kerabat yang tidak meyakini berasal dari sebuah nenek moyang bersama. Kekerabatan bilateral dapat diartikan sebagai sistem yang mengadopsi dua pihak, dalam kasus ini pihak ayah dan pihak ibu memilliki kedudukan yang sama pentingnya atau bisa juga tidak penting. Masyarakat bilateral tidak mengarah pada sistem keturunan bersama tetapi lebih kepada garis horizontal, yakni perpindahan dari sistem yang tertutup menjadi relatif lebih jauh dari sekedar hanya berdasarkan sistem nenek moyang bersama (Ember \& Ember, 2007: 386-387).

Valeri dalam tulisannya fragments from forest and libraries mengatakan bahwa afiliasi lebih luas dari sekedar penarikan garis kerabat individu kepada klan tertentu. Afiliasi tidak hanya mencakup garis keturunan saja namun juga berkaitan erat dengan aturan-aturan menetap sesudah perkawinan, dan pola kekuasaan di dalam keluarga. Demikian ia mengatakan;

"...Although every exchange that accompanies marriage forms part of a continuous flow between wife-givers and wife-takers, three prestations are essential for a marriage to achieve its full status. Each of these marks a stage in a cycle that involves a change in affiliation, residence, names, and associated prohibitions." (Valeri, 2001:142).

la melihat afiliasi sebagai sejumlah aturan, norma, dan relasi-relasi kuasa yang terbentuk di dalam sistem organisasi sosial, terutama berkaitan dengan bagaimana posisi dan peran suami/istri di dalam keluarga, dan bagaimana hak-hak dan kewajiban mereka terhadap keturunannya. Menurutnya konsep afiliasi tidak hanya terbatas pada sistem garis keturunan saja, melainkan lebih dari itu mencakup pola relasi kekuasaan suami dan istri, pola post marital residence, serta posisi dan status keturunannya. Melalui penelitiannya di Indonesia Timur, ia merumuskan konsep afiliasi yang di dalamnya terkandung relasirelasi kuasa baik pihak suami ataupun istri, dan bagaimana relasi-relasi kuasa itu dipraktikkan di dalam post marital residence dan keturunannya.

Konsep afiliasi yang diusung Valeri juga dipengaruhi oleh konsep struktur sosialnya Radcliffe-Brown dimana sistem afiliasi sebuah masyarakat merupakan unsur terpenting dari struktur sosial yang di dalamnya terdapat relasi-relasi sosial antar 
anggotanya. Struktur kekerabatan adalah satu media dimana terdapat relasi-relasi yang sifatnya diadik di antara para anggotanya, seperti hubungan ayah dengan anak laki-laki maupun seorang saudara lakilaki ibu dengan anak laki-laki saudara perempuannya. Struktur sosial dasar yang lebih kompleks didasarkan pada sebuah jaringan yang menghubungan antar anggota masyarakat yang ditetapkan melalui hubungan genealogis.

"...l regard as a part of the social structure all social relations of person to person. The kinship structure of any society consist of a number of such dyadic relations, as between a father and son, or a mother's brother and his sister's son. The whole social structure is a based on a network of such relations of person to person, established through genealogical connections" (Radcliffe Brown, 1979: 191).

Selanjutnya, struktur sosial juga mencakup di dalamnya diferensiasi para individu pada kelas-kelas sosial tertentu yang dibentuk oleh peran sosial mereka masing-masing di dalam kelompoknya. Seperti perbedaan posisi laki-laki dan perempuan, posisi kepala suku dan anggota masyarakatnya, posisi pimpinan dan karyawan, dan masih banyak faktor lain yang membentuk relasi-relasi sosial, termasuk perbedaan klan atau suku bangsa.

"...I include under social structure the differentiation of individuals and of classes by their social role. The differential social positions of men and women, of chiefs and commoners, of employers and employees, are just as much determinants of social relations as belonging to different clans or different nations" (Radcliffe Brown, 1979: 191192).

Valeri mendeskripsikan adanya perubahan-perubahan yang terjadi terutama perubahan dari matrilateral menjadi patrila teral yang berpengaruh terhadap relasi kuasa di dalam keluarga. Menurutnya, perubahan relasi kuasa terjadi mengikuti arah perubahan residensi dan sistem garis keturunan. Kekuasaan suami ataupun istri dapat menempati posisi superior maupun inferior apabila terjadi perubahan pada sistem garis keturunan dan pola resi densinya. Konsep afiliasi ini ia tampilkan pada sistem kekerabatan di Huaulu. Menurutnya, sistem afiliasi menjadi bagian tahapan dari sebuah silkuls aliansi yang sempurna (Valeri, 2001: 142-145).

Aturan dalam sistem afiliasi menjadi bagian terpenting yang mengatur posisi dan peran di dalam keluarga. Sebagaimana yang jelaskan Valeri dalam penelitiannya bahwa di Huaulu terdapat berbagai aturan dalam sistem perkawinan. Aturan-aturan itu meliputi upacara, mahar, hubungan sosial dan aturan-aturan tempat tinggal. Dalam sistem afiliasi, mahar memiliki peran yang sangat penting karena menentukan siapa yang berkuasa dan pada siapa kekuasaan itu dijalankan. mahar juga menentukan siapa yang berhak atas keturunan mereka. Pola residensi juga menjadi bagian penting dari aturan afiliasi.

Valeri mengatakan pola residensi masyarakat Huaulu ketika pembayaran mahar pertama terselesaikan adalah uxorilokal. Pada tahap uxorilokal sistem afiliasi Huaulu masih dianggap belum sempurna siklus aliansinya, karena masyarakat Huaulu pada akhirnya harus berafiliasi secara agnatik, yaitu sistem garis keturunan pada pihak laki-laki saja dan pola residensi berubah dari uxorilokal menjadi virilokal (Valeri, 2001: 142-143).

\section{Metode Penelitian}

enelitian ini menggunakan pendeka tan kualitatif dengan metode etno grafi. Metode etnografi digunakan untuk mempelajari makna dari setiap perilaku, bahasa, dan interaksi yang terjadi dalam komunitas Lematang. Digunakannya metode etnografi karena fenomena yang diteliti mengharuskan kedalaman observasi dan interpretasi perilaku manusia secara detil, termasuk untuk menangkap makna realitas sosial budaya berdasarkan sudut pandang subyek yang diteliti (dalam rangka mendapatkan native's point of view). Lebih lanjut digunakannya metode etnografi juga karena penelitian ini membutuhkan strategi yang dapat memberikan ruang lebih besar kepada peneliti untuk mengeksplorasi secara mendalam budaya dan sistem sosial sebagai sebuah bagian yang fundamental dari pengalaman dan pengetahuan 
manusia. Alasan yang mendasar dari penggunaan metode etnografi juga tertuju kepada ketercapaian data primer atau data dari pelaku secara langsung dan melakukan interaksi dengan orang yang diteliti. Oleh karena itu, teknik pengumpulan data yang digunakan dalam penelitian ini meliputi; pengamatan terlibat (partisipant obser vation), wawancara mendalam (depth Interview), dan studi kepustakaan (literatur review).

\section{D. "Kampi" Pola Perkawinan Matrilokal di Lematang}

$\mathrm{M}$ odel perkawinan yang sangat dianjurkan di dalam komunitas Lematang adalah tejujur $^{6}$, sistem perkawinan semacam ini adalah sistem yang umumnya terjadi di masyarakat karena sesuai dengan sifat-sifat patrilinial Lema tang. Tejujur memiliki pengertian memberikan mas kawin dan biaya perkawinan (mahar/pintaan) kepada pihak perempuan, artinya laki-laki memiliki kekuatan penuh dalam mengambil wanita dari klan lain, ataupun perempuan memiliki kuasa penuh dalam menentukan mahar yang akan diterimanya. Pada perkawinan semacam inilah terjadi tawar-menawar sampai terjadi kemufakatan yang disebut dengan istilah maduke rasan. Pola perkawinan semacam ini dianggap paling ideal oleh komunitas Lematang maupun masyarakat lain di Sumatera Selatan.

Istilah tekampi berasal dari istilah lokal kampi atau ngampi yang berarti ambil atau mengambil; jika dihubungkan dengan perkawinan, maka kampi atau ngampi adalah mengambil anak laki-laki dari keluarga atau klan lain untuk meneruskan garis keturunannya dan menjadikan laki-laki tersebut suami dari anak perempuannya. Tekampi artinya terambil, si laki-laki tersebut terambil dan ikut dengan istrinya atau keluarga istrinya secara matrilokal. Tugas laki-laki tersebut sebagai penerus garis keturunan di keluarga perempuan yang menikahinya itu. Tugas laki-laki tekampi tidak hanya itu, ia juga diharuskan menjaga harta pusaka secara turun temurun, ia juga harus mengurus orang tuanya (mertua) hingga meninggal, dan saudara-saudara sekandung istrinya hingga mereka hidup secara mandiri.

${ }^{6}$ Mengarah pada pola perrkawinan patrilokal
Pada pola perkawinan ini, pihak perempuan memiliki kekuatan penuh untuk memberikan biaya perkawinan (mahar/pintaan) kepada laki-laki yang dikampinya. Laki-laki yang akan dinikahi hanya diminta menyiapkan mas kawin alakadarnya saja untuk syarat ijab kobul, sedangkan untuk biaya perkawinan dibebaskan. Semua biaya men jadi tanggungjawab pihak perempuan, pola perkawinan semacam ini mengarah kepada pola perkawinan matrilokal.

\section{Kampi; Ciri-ciri, dan Jenisnya}

awin kampi secara hukum adat terbagi ke dalam dua macam yaitu: tekampi tegoh ${ }^{7}$ dan tekampi semen tara. Tekampi tegoh adalah sistem kawin kampi yang statusnya amat kuat bagi seorang laki-laki untuk masuk ke dalam garis keturunan istrinya, mereka menetap secara matrilokal, dan berafiliasi secara matrilinial ke keluarga istri seumur hidup nya, bahkan jika ia meninggal harus dikuburkan bersama dengan kuburan orang tua istrinya, dan apabila ia keluar dari garis keturunan itu, ia harus pergi dengan tanpa membawa apapun termasuk anak-anaknya. Tekampi tegoh jelas memiliki beban tugas yang berat seperti yang akan diuraikan pada subbab berikutnya, tekampi tegoh juga amat rawan dengan berbagai tekanan psikologis yang harus ditanggung si pelaku kawin kampi tersebut.

Tekampi sementara adalah kampi yang lemah, sistem ini hanya berlaku sementara bagi laki-laki yang menghargai permintaan kampi keluarga perempuan, namun dirinya juga menghargai dan menjunjung tinggi harga diri ia dan keluarganya. Tekampi jenis ini biasanya telah melalui proses negosiasi yang sulit karena karena masing-masing pihak saling mempertahankan garis keturunannya. Te kampi sementara selain bertugas sebagai penerus keturunan di keluarga istri, ia juga masih tetap sebagai penerus keturunan dikeluarganya. Jadi tekampi sementara sifatnya lebih fleksibel.

Seiring dengan perkembangan zaman, saat ini lebih banyak yang menganut sistem kampi sementara daripada kampi tegoh. Kampi sementara ini biasanya terjadi karena ada tungguan terikat

${ }^{7}$ Tegoh adalah Istilah lokal yang berarti kuat dan 93 | P a g e 
artinya si pelaku kawin kampi terutama orang tua pihak perempuan meminta si lakilaki berafiliasi sementara ke keluarganya sampai ada anak-anak lainnya yang menikah. Jadi si laki-laki yang dikampi sementara ini, setelah adik iparnya menikah dalam status kampi tegoh, maka ia boleh keluar dari garis keturunan keluarga istri dan kembali ke garis keturunan keluarganya secara agnatik. Pola pembagian harta waris dan pola residensinyapun berbeda dengan tekampi tegoh, pola residensi bisa berubah, bisa patrilokal, virilokal, avunkulokal, atau neolokal. Oleh karena itu, kampi sementara tidak disebut kampi oleh masyarakat, tetapi lebih dikenal dengan istilah ngireng. Ngireng artinya mengiring, yakni mengiringi saudara perempuan lain yang akan dikampi secara tegoh atau mengiringi saudara laki-lakinya yang masih kecil dan belum bisa menikah atau belum mandiri.

\section{Komponen dan Aturan-aturan Kampi}

A dat kampi sifatnya sangat lembut karena proses negosiasi untuk menarik pihak keluarga laki-laki agar menyetujui anaknya masuk dalam garis keturunan keluarga perempuan tidaklah mudah, biasanya dengan berbagai persya ratan, di antaranya si laki-laki tidak bersedia mengeluarkan biaya sedikitpun untuk pelaksanaan ritual perkawinannya hingga selesai, jadi semua biaya dipersiapkan oleh pihak keluarga perempuan, termasuk mas kawin sebagai salah satu syarat perka winan ${ }^{8}$.

Tugas laki-laki yang melakukan kawin kampi tergolong sangat berat. Menurut tokoh adat, tidak banyak orang yang mampu menjalani kawin kampi di tengah sistem patrilinial yang berlaku di Lematang. Pertama ia harus meneruskan garis keturunan mertuanya, ia sebagai

8 Meskipun secara agama, mas kawin tetap menjadi kewajiban pihak laki-laki, namun dari temuan data lapangan ada saja subjek tekampi tidak membawa apapun ketika meminang, termasuk mas kawin. Pada kondisi ini mas kawin biasanya disiapkan oleh pihak keluarga perempuan, diberikan atau dipinjamkan kepada laki-laki, sehingga seolah-olah mas kawin tersebut adalah milik mempelai laki-laki untuk diberikan kepada mempelai perempuan saat ijab qobul, pada kenyataannya sebagian subjek laki-laki kawin kampi hanya secara simbolis saja sebagai pemilik mas kawin tersebut. penunggu jurai atau penerus garis darah keluarga (penegak jurai). Dengan demikian ia terpaksa keluar dari garis keturunan keluarganya sendiri (menjadi jurai agayan ${ }^{9}$ ). Begitupun bagi orang tua kandungnya, mereka akan merasa bersalah karena anak laki-lakinya itu terbuang atau dibuang dari garis keturunannya, oleh karena itu kebanyakan dari orang tua tidak akan bersedia jika anak laki-lakinya dikampi.

Kedua, stigma buruk yang dilekat kan kepada para pelaku kawin kampi terutama subjek laki-laki juga dianggap menyebabkan tekanan psikologis si laki-laki itu sendiri berikut juga orang tuanya. Lakilaki maupun orang tua si laki-laki yang menjalani kawin kampi dianggap lemah, tidak mau berusaha, pemalas, tidak memiliki harga diri karena rela dibeli, serta hidupnya menumpang dan mengharap harta istri, pelaku pasrah menerima stigmatisasi semacam ini. Ketiga laki-laki yang menjalani kawin kampi diharuskan menetap secara matrilokal, mengurus rumah tangganya, mengurus orang tua istrinya hingga meninggal, dan mengurus saudara kandung istrinya hingga mereka mandiri.

Keempat laki-laki yang menjalani kawin kampi umumnya tertekan berat secara psikologis ketika ia harus hidup bersama mertua dan keluarga istrinya, secara otomatis ia tidak memiliki kekuasaan untuk melakukan dan menentukan tindakan nya karena berada di bawah otoritas keluarga perempuan, dan selama hidupnya selalu dikendalikan istrinya. Kelima pelaku kawin kampi memiliki tugas menjaga harta pusaka peninggalan orang tuanya secara turun temurun, harta pusaka tidak boleh berpindah tangan kepada yang bukan garis keturunan keluarganya.

Tugas yang amat berat inilah membuat tidak semua orang bisa menjalani kawin kampi, hanya orang-orang tertentu saja yang bersedia menjalani sebagai orang yang tekampi. Setiap laki-laki yang melakukan kawin kampi maka ia terikat oleh perjanjian adat yang dilakukan ketika ia

${ }^{9}$ Jurai agayan dalam garis patrilinial adalah istilah lokal untuk menyebut peran perempuan dalam menciptakan hubungan besan, atau dalam arti lain posisi perempuan adalah sebagai keturunan yang dibagi-bagikan, maksudnya adalah sebagai penerus garis keturunan di kelompok patrilinial lain Ssedangkan dalam perspektif matrilinial yang menjadi jurai agayan adalah laki-laki yang tekampi. 
menikah dahulu, mereka tidak bisa melanggarnya, karena mereka memiliki keyakinan apabila mereka melanggar maka akan mengalami celaka atau kutukan dari leluhur mereka. Tidak hanya itu, sesuai aturan adat bahwa pelaku kawin kampi jika mereka melanggar, terutama si laki-laki pergi atau melepaskan tanggungjawabnya, maka ia harus keluar dari garis keturunan istrinya dengan tidak membawa apapun, bahkan anaknya sekalipun, ia hanya membawa baju di badan. Sehingga bagaimanapun keadaannya mereka harus tetap bertahan menjalaninya.

Sistem kawin kampi tidak serta merta terjadi begitu saja, sistem kawin kampi dilakukan karena beberapa faktor, misalnya pertama faktor tidak memiliki anak laki-laki, karena masyarakat Lematang umumnya menganut garis keturunan patrilinial maka apabila ia tidak memiliki anak laki-laki garis keturunannya dianggap berhenti sampai di situ. Untuk melanjutkan keturunannya, maka ia harus mengampikan anak perempuannya. Jika ia hanya memiliki anak perempuan saja maka anak perempuan tertualah yang akan menjalani kawin kampi. Jika suami anak perempuan tertua enggan dikampi maka diadakan negosiasi kampi sementara sampai adiknya menikah, dan kemudian diteruskan kepada adik perempuannya sebagai tekampi tegoh.

Faktor yang kedua biasanya si lakilaki yang akan dikampi berada dalam kondisi ekonomi lemah, tidak memiliki pekerjaan, ataupun peninggalan harta waris dari keluarganya. Dengan proses negosiasi keluarga maka si laki-laki tersebut bersedia dikampi dan masuk ke garis keturunan istrinya. Faktor ketiga biasanya karena orang tua si perempuan terlalu sayang dengan anaknya karena anak perempuan nya hanya satu orang sedangkan yang lainnya laki-laki, maka boleh saja orang tuanya mengampikan anak perempuannya itu. Jika anak perempuannya itu melakukan kawin kampi maka kedudukannya dalam ahli waris akan sejajar dengan anak lakilakinya.

Bagi keluarga perempuan yang anaknya melakukan kawin kampi, mereka harus siap secara materil dan moril untuk melakukan negosiasi terhadap pihak keluarga laki-laki, karena biasanya laki-laki yang akan dikampi menolak atau mengajukan beberapa persyaratan kepada pihak perempuan, mereka mengadakan semacam perjanjian dan kesepakatan kedua belah pihak bagaimana sifat kampi yang akan dijalaninya apakah tegoh apakah sementara tergantung kepada kesepakatan. Jika orang tua memiliki anak hanya seorang dan perempuan, maka kawin kampi berlaku kuat yakni kampi tegoh, karena hanya dia yang memegang kendali keturunan dan kendali terhadap harta orang tuanya. Begitupun jika si orang tua itu memiliki anak perempuan lebih dari satu maka yang berhak terhadap kendali keturunan, harta pusaka, dan merawat orang tua hingga meninggal adalah anak perempuan yang dikampi.

\section{Tabu dan Mitos dalam} Perkawinan Kampi

ebagai masyarakat patrilinial,
masyarakat Lematang menginginkan
adanya kemapanan dalam struktur mereka. Aturan-aturan dalam struktur itu dikonstruksi oleh mereka manakala sistem ideal di dalam struktur itu tidak produktif lagi. Dengan sendirinya sistem yang menurut kolektif itu tidak ideal, terpaksa digunakan sebagai ranah solusi dalam mereproduksi struktur agar tetap relevan dengan apa yang menjadi harapan dan kesepakatan kolektifnya (Rudyansjah, 2015: 16). Kawin kampi sebagai praktik sosial yang dianggap tidak ideal terpaksa dilakukan sebagai solusi merekonstruksi struktur yang tidak produktif itu. Meskipun pada praktiknya dianggap berlawanan dengan struktur asli mereka, pemahaman kolektif yang demikian berada pada tataran struktur luar. Pemahaman yang demikian lambat laun terinternalisasi di dalam tindakan dan pikiran kolektif sehingga praktik tersebut menjadi sesuatu yang dilarang. Makna larangan itu ada pada konsekuensi aturan afiliasi dan relasi kuasa, laki-laki yang dikampi akan berafiliasi secara genealogis ke dalam garis keturunan keluarga pihak istri. Melalui pola afiliasi semacam inilah dianggap melemahkan simbol-simbol maskulinitas laki-laki, karena bergesernya patriarki. Laki-laki yang melakukan kampi harus tinggal di pihak istri secara matrilokal, dari sini akan memberikan peluang kekuasaan istri menjadi dominan dalam relasi kuasa. 
Laki-laki yang dikampi dianggap memiliki hutang mahar yang harus dibayarkan kepada pihak pemberi istri. Pembayarannya bukan dengan uang, tetapi dengan pengabdian diri seorang laki-laki kepada keluarga perempuan. Pengabdian itu bera gam bentuknya dari bentuk yang ringan hingga ke yang paling berat, bentuk yang paling berat adalah konsekuensi berafiliasinya laki-laki tersebut ke garis keturunan keluarga istrinya secara matrilinial. Sejak itulah garis keturunan di keluarga si laki-laki itu sendiri menjadi terputus dan hilang. Umumnya laki-laki yang bersedia dikampi oleh pihak perempuan adalah laki-laki yang putus asa dan berada pada kondisi sosial ekonomi lemah. Namun sesungguhnya laki-laki yang bersedia menjalani kampi bukanlah laki-laki sembara ngan, karena ia harus siap lahir batin menjalankan tugas yang berat itu. Laki-laki yang menjalani kawin kampi menganggap dirinya sebagai laki-laki yang berjiwa besar. Masyarakatpun memandang bahwa laki-laki yang berani menjalani kampi adalah laki-laki yang nekat dan berani mengambil resiko.

Laki-laki yang sudah bertekad untuk menjalani kampi, maka ia harus mematuhi segala larangan yang ditabukan oleh aturan adat kampi, larangan inilah yang berada di antara sakral dan profan itu. Tabu dipahami sebagai sesuatu larangan suci, tabu merupakan batasan antara yang kudus dengan yang duniawi, dan apabila terjadi pelanggaran atas batasan itu maka konsekuensinya adalah bahaya suprana tural (Valeri, 2000:43-44).

Pelaku kampi laki-laki ditabukan untuk kembali pada garis keturunan keluarganya selama ia menjalani kawin kampi, bahkan jika dirinya meninggalpun harus dimakamkan di pemakaman keluarga istrinya. Tidak hanya dirinya, keturunannya pun tabu jika menetap atau tinggal serumah dengan keluarga dari ayahnya. Larangan ini tidak boleh dilanggar oleh pelaku kampi, karena berhubungan dengan sesuatu yang disakralkan. Hal-hal yang ditabukan lainnya dalam adat kampi misalnya perginya lakilaki dari rumah tanpa pemberitahuan dan tanpa alasan yang jelas hingga berbulanbulan meninggalkan anak dan istrinya. Kasus ini dianggap sebagai pengunduran diri atau menyerahnya seorang laki-laki dari sistem kampi, dan dianggap melalaikan tugas dan tanggungjawab sebagai seorang tekampi. Konsekuensinya juga tergolong berat, ia harus keluar dari garis keturunan pihak istrinya dengan tanpa membawa apapun, baik harta maupun keturunannya.

Sebaliknya, di pihak keluarga pem beri istri juga memiliki hal-hal yang dianggap tabu. Laki-laki yang tidak memiliki keturunan laki-laki, maka garis keturunannya dianggap berhenti. Kondisi demikian tidak bisa dibiarkan begitu saja. Apabila dibiarkan, akan dianggap sebagai pelanggaran terhadap tabu. Masyarakat Lematang sa ngat menghormati leluhur mereka, dan selalu berusaha menjaga agar garis kerabat pada klan agnatiknya tidak hilang. Hal ini menjadi ketakutan bagi mereka jika tidak mampu menegakkan dan meneruskan pertalian darah nenek moyangnya melalui pranata perkawinan secara matrilokal itu. Namun sayangnya, kondisi itu tidak serta merta diterima kolektif sebagai pranata yang ideal, karena kolektif memaknai situasi ini sebagai tindakan yang menciderai sistem patriarki mereka, pada akhirnya mereka berada pada kebingungan kategori.

\section{Post Marital Residence}

$\mathrm{P}$ erbedaan posisi dan peran sosia individu-individu dalam struktur keke rabatan juga dipengaruhi oleh sistem post marital residence. Post marital residence itu sendiri terdiri dari patrilokal residence yaitu pola residensi di mana istri dan anak-anak tinggal di kediaman suami atau di sekitar kediaman ayah suami. Matrilocal residence adalah pola residensi di mana suami dan anak-anak tinggal di kediaman istri atau di sekitar ayah istri. Pola bilocal residence adalah pola tempat tinggal yang mengadopsi keduanya yakni pola matrilokal dan patrilokal. Sedangkan avunculocal residence adalah pola kedia man pasangan dan anak-anak berada di dekat kediaman saudara laki-laki ayah/ibu. Tiga pola di atas (patrilokal, matrilokal, dan avunkulokal) merupakan bentuk tunggal dari sistem residensi yang kemudian disebut dengan istilah unilocal residence. Tipe selanjutnya adalah neolocal residence yaitu pola residensi independen yang terbentuk sebagai kesepakatan pasangan dan keluarga masing-masing pasangan untuk memisahkan diri atau tidak terikat pada beberapa pola residensi yang disebutkaan di atas (Ember \& Ember, 2007:382). 
Pola residensi yang berlaku umum di Lematang adalah unilokal, bisa berupa patrilokal, matrilokal, atau neolokal, tergantung kesepakatan kedua belah pihak. Pola post marital residence tidak selalu tergantung pada jenis perkawinannya, namun sebaliknya jenis perkawinan tertentu (tekampi/tejujur) akan memengaruhi pola residensi yang berlaku. Selain pola tersebut, ada juga sebagian kecil yang menganut pola avunkulokal. Pola perkawinan tejujur umumnya pola residensi yang berlaku adalah patrilokal, virilokal (neolokal ikut suami) meski tidak sedikit pula yang menganut pola matrilokal, namun pola matrilokal pada sistem afiliasi patrilinial sifatnya hanya sementara saja, biasanya karena faktor ekonomi si laki-laki tersebut, apabila ia telah mampu secara ekonomi maka ia akan menganut pola neolokal secara independen.

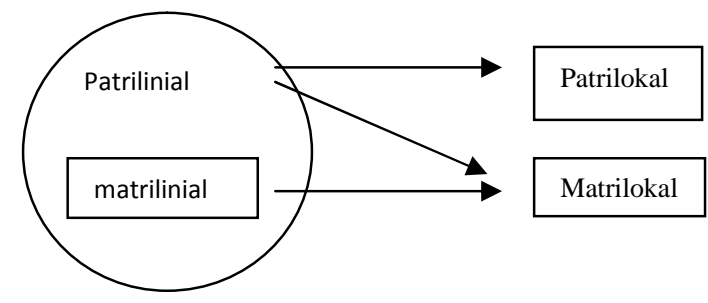

Bagan 1. Pola Residensi di Lematang

Pada pola perkawinan tekampi atau kawin kampi, pola residensi yang berlaku umum adalah matrilokal, namun tergantung jenis kampinya, apabila kampinya adalah kampi tegoh maka pola umum residensinya adalah matrilokal. Namun, jika kampinya adalah kampi sementara atau ngireng pola residensinya bisa dinegosiasikan antar keluarga, bisa matrilokal, bisa juga neolokal. Pola matrilokal pada kampi sementara sifatnya tidak masif, semacam sistem kontrak melalui kesepakatan kedua keluarga, (menurut masyarakat lokal biasa nya kampi sementara karena ada yang ditunggu misalnya saja menunggu sampai adik perempuannya menikah secara kampi tegoh, lalu menggantikan kedudukan kakak perempuanya sebagai kampi sementara), apabila masa kampi kakaknya tersebut telah habis, maka ia diperkenankan untuk meninggalkan rumah orang tua, sehingga pola yang dianut adalah pola residensi neolokal.

\section{Afiliasi Genealogis}

ola afiliasi yang berkaitan dengan garis keturunan secara umum terdiri dari tiga bentuk, yaitu sistem garis keturunan unilinial, ambilinial, dan bilateral. Sistem unilinial dan ambilinial mendasarkan pada ketentuan keturunan atau hubungan individu dengan kerabatnya yang mengacu kepada nenek moyang bersama. Sistem keturunan unilinial akan memperlihatkan berafiliasinya seseorang pada salah satu kelompok keturunan melalui garis keturunan dari salah satu nenek moyang, hanya melalui pihak laki-laki maupun perempuan saja. Sistem garis keturunan unilinial bisa berupa patrilinial atau matrilinial saja. Sedangkan ambilinial menarik garis keduanya. Sistem bilateral tidak berda sarkan pada aturan keturunan atau nenek moyang bersama dan tidak dikonstruksi secara jelas oleh masing-masing kelompok klan (Ember \& Ember, 2007).

Berdasarkan pada temuan data di lapangan sistem afiliasi garis keturunan pada masyarakat Lematang adalah patrilinial namun bagi komunitas Lematang yang menganut sistem kawin kampi maka pola afiliasinya menganut sistem garis keturunan patrilinial dan matrilinial sekaligus dalam satu garis kerabat/klen, atau yang kemudian disebut dengan istilah sistem afiliasi ambilinial atau unilinial berganda. Masyarakat Lematang bukanlah komunitas yang lemah dalam sistem patrilinial, justru menjadi sistem afiliasi yang amat kuat, hal ini diketahui dari pentingnya kedudukan anak laki-laki dalam garis keturunan, tidak hanya sebagai penerus generasi tetapi juga sebagai ahli waris bagi harta peninggalan orang tuanya, sedangkan anak perempuan berkedudukan subordinat, hanya sebagai pencipta hubungan besan dengan kelompok kerabat yang lain yang disebut dengan istilah jurai agayan (menyebar dan menegakkan garis keturunan kerabat pa trilinial lain).

Melalui sejumlah informan yang saya temui, mereka menganggap dirinya ataupun kehidupan keluarganya menjadi tidak sempurna apabila ia tidak memiliki anak laki-laki, sehingga kawin kampi menjadi alternatif untuk menjaga dan meneruskan garis keturunannya secara agnatik bagi orang tua perempuan, dan matrilinial bagi keturunannya. Bagi laki-laki yang menjalani kawin kampi maka ia harus 
berafiliasi ke dalam garis keturunan pihak istrinya, afiliasi semacam ini adalah konsekuensi dari hutang mahar yang timbul pada saat terjadinya perkawinan. Laki-laki yang dikampi maka ia harus menjadi penerus dari garis keturunan mertuanya, sedangkan di dalam keluarganya sendiri ia sudah dihapus dari daftar silsilah keturunan yang disebut dengan istilah jurai tebuang atau keturunan yang terbuang.

Masyarakat Lematang sangat menjunjung tinggi patriarki di dalam keluarga, sehingga anak laki-laki menjadi sangat penting kedudukannya dibandingkan anak perempuan, terutama karena adanya kepentingan akan menjadi penerus keturunan. Namun dalam kasus kawin kampi tidak demikian, karena anak-anak yang merupakan keturunannya akan berafiliasi ke dalam garis keturunan ibunya (matrilinial). Pada generasi selanjutnya apabila pelaku kawin kampi memiliki anak laki-laki dan anak laki-lakinya tersebut menikah secara patrilokal maka sistem garis keturunan selanjutnya yang berlaku adalah patrilinial.

Apabila pelaku kawin kampi tersebut tidak memiliki anak laki-laki, maka kawin kampi akan diteruskan oleh keturunannya, sehingga pola afiliasinya akan bertahan pada pola matrilinial, ini berlaku sampai memiliki anak laki-laki. Jika ia memiliki anak laki-laki kemudian anak laki-lakinya tersebut dikampi oleh keluarga patrilinial lain dalam perkawinan matrilokal maka secara otomatis anak laki-lakinya tersebut menjadi jurai agayan, dan berafiliasi ke dalam garis keturunan istrinya. Dalam hal ini meskipun pasangan yang melakukan kawin kampi tersebut telah memiliki anak laki-laki, maka ia harus tetap mempertahankan kawin kampi pada anak perempuannya, karena anak laki-lakinya berafiliasi ke dalam kelompok garis kerabat patrilinial lain.

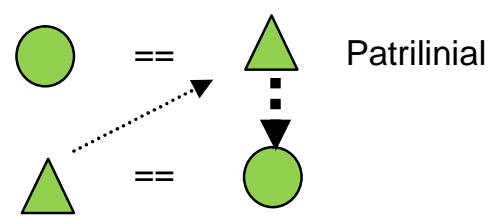

Ket.

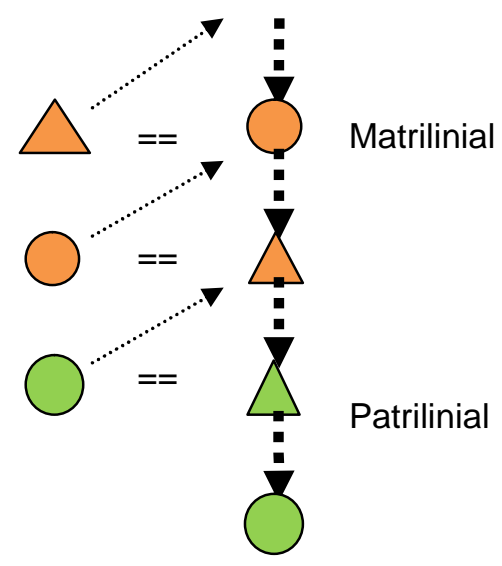

$$
\begin{aligned}
& \ldots=\text { = Garis Keturunan } \\
& ==\quad=\text { Garis Perkawinan } \\
& \text { …...... } \rightarrow \text { = Garis Perubahan Afiliasi }
\end{aligned}
$$

Bagan 2. Bagan tentang rule affiliation pada perkawinan kampi

\section{Struktur Organisasi Sosial}

$O_{\text {dal }}$ etiap komunitas atau suku memiliki struktur organisasi sosial yang di dalamnya terdapat peran dan posisi tiap-tiap anggota keluarga, termasuk juga komunitas Lematang. Struktur terkecil dalam sistem kekerabatan patrilinial di Lematang disebut Jurai ${ }^{10}$ sedangkan struktur yang lebih besar disebut Karang Kampung ${ }^{11}$. Karang Kampung adalah struktur organisasi sosial yang terdiri dari beberapa Jurai yang diikat oleh nenek moyang bersama. Di dalam Jurai, Masingmasing anggota Jurai tersebut memiliki peran dan fungsi sesuai dengan penyebutannya. Status sosial tertinggi dalam sistem organisasi sosial Lematang dipegang oleh Tue Batin ${ }^{12}$. Tue Batin dipegang oleh saudara laki-laki ayah. Tue Batin memiliki kekuasaan terhadap keturunan dari saudara laki-lakinya. la juga memiliki relasi kuasa yang kuat terhadap saudara kandungnya, serta berperan

10 Jurai dalam istilah lokal adalah keturunan, jurai dalam ssistem organisasi social Lematang berarti institusi keluarga

${ }^{11}$ Karang kampung dalam istilah lokal adalah gabungan dari beberapa jurai dalam satu nenek moyang, secara antropologis disebut klan.

${ }^{12}$ Tue batin merupakan seseorang yang memiliki pertalian darah yang amat kuaat dengan penegak jurai. Biasanya tue batin adalah saudara laki-laki ayah dalam sistem patrilinial, atau saudara laki-laki ibu dalam sistem matrilinial, dalam istilah lokal disebut mamak. 
sebagai pengganti ayah jika ayah sudah tiada.

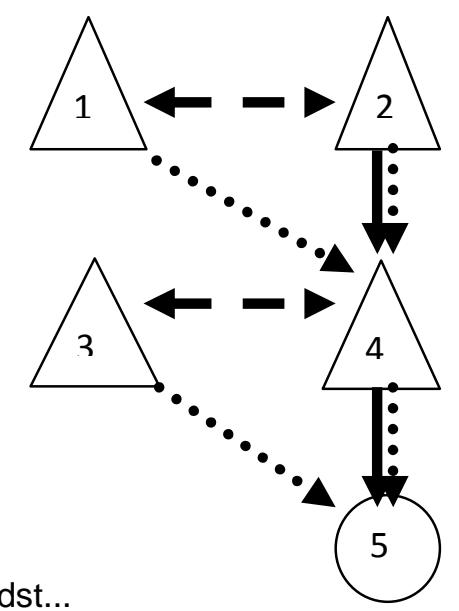

Ket.
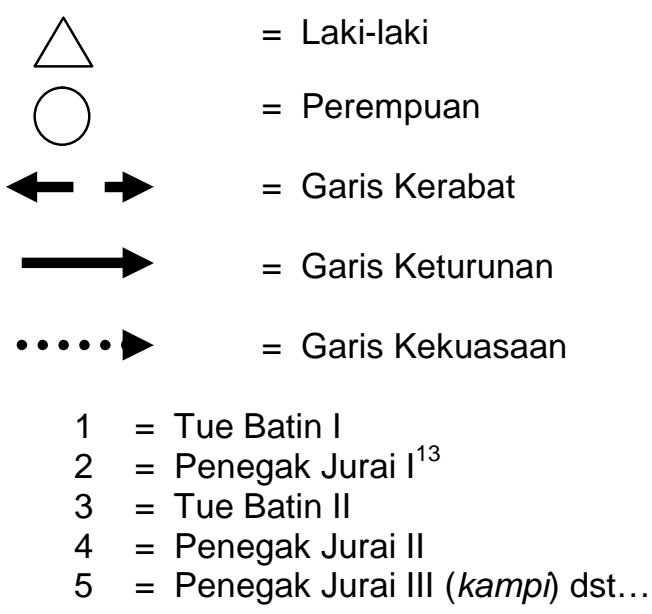

\section{Bagan 3. Struktur Organisasi Sosial di Lematang}

Pada perkawinan kampi jika pelaku kampi (penegak jurai III) tidak memiliki saudara laki-laki, maka tue batin diambil dari anak laki-laki saudara laki-laki ayahnya begitu seterusnya.

\section{Harta Waris}

arta peninggalan atau harta waris menjadi bagian yang terpenting dalam sistem kawin kampi, karena berkaitan dengan sistem afiliasi mereka,

13 Penegak Jurai adalah seseorang ahli waris keturunan yang bertugas meneruskan garis keturunan/pertalian darah nenek moyang. terutama garis keturunan. Sebuah keluarga yang anak perempuannya melakukan kawin kampi maka ia memiliki hak atas harta orang tuanya setidaknya $90 \%$ dari jumlah harta, termasuk rumah yang ditinggali orang tuanya. Sedangkan sisanya dibagi-bagikan kepada saudaranya melalui kemufakatan tetue jurai. Karena tidak ada anak laki-laki maka posisi anak perempuan yang dikampi akan menjadi anak laki-laki secara adat.

Sebagai penerus garis keturunan orang tuanya, perempuan kampi sepe nuhnya berhak atas harta yang ditinggalkan oleh orang tuanya, kebun, rumah, atau yang lainnya menjadi miliknya. Sedangkan saudarannya yang lain tidak memiliki kekuatan terhadap harta peninggalan, saudara kandung yang lain hanya akan diberikan harta jika ada persetujuan dari anak yang dikampi. Melalui kebijakan musyawarah, jika setuju, maka saudaranya diberikan harta peninggalan, namun sekedarnya saja (sepengenjuk ${ }^{14}$ ). Apabila anak perempuan yang dikampinya memiliki saudara kandung laki-laki maka bagian keduanya adalah setara atau disamakan, berdasarkan hukum adat.

Kebijakan pembagian harta waris yang demikian dikarenakan anak perem puan yang dikampi, berkedudukan sebagai anak laki-laki (penegak jurai/tegakan lanang), dan menantu dari anak yang di kampinya itu akan berkedudukan sebagai anak perempuan. Sedangkan anak perempuan dalam adat melayu Lematang tidak memiliki hak atas harta pusaka, karena ia berperan sebagai jurai agayan. Maka laki-laki yang menjalani kawin kampi akan berstatus sebagai jurai agayan sehingga garis keturunannya terputus dari garis keturunan keluarganya sendiri.

Jika anak perempuan lain yang berstatus sebagai jurai agayan mendapat kan harta waris melalui persetujuan anak kampinya, yang diberi secara sepengenjuk saja, maka demikian juga yang berlaku pada anak laki-laki yang masuk dalam kampi pihak perempuan. Anak laki-laki yang dikampi maka ia akan dihapus dari daftar ahli waris keluarganya sendiri, ia akan berstatus sebagai jurai agayan, sehingga

${ }^{14}$ Kata sepengenjuk merupakan istilah lokal yang memiliki makna: tindakan memberikan sesuatu kepada orang lain dengan tidak ditentukan berapa jumlahnya, atau memberi sesuatu dengan seiklasnya. 
dikeluarganya sendiri ia tidak mendapat harta apapun terkecuali ada persetujuan dari penegak jurai di keluarganya. Misalnya saja persetujuan dari saudara laki-lakinya, sehingga melalui kesepakatan, ia diberi harta dari hasil pembagian di keluarganya, namun sifatnya hanya sepengenjuk saja.

Harta peninggalan berupa rumah orang tuanya menjadi suatu keharusan diberikan kepada anak yang dikampinya karena dialah yang akan menjaga rumah itu dan mengurus kedua orang tuanya hingga meninggal. Rumah yang merupakan peninggalan orang tuanya ini telah melalui proses turun-temurun dari generasi ke generasi, sehingga wajib dipertahankan keberadaannya. Rumah tersebut harus dirawat dan dijaga, tidak boleh dijual ataupun berpindah pemilik. Fungsi rumah tersebut adalah tempat berkumpulnya keluarga besar ketika hari-hari besar, atau untuk acara keluarga lainnya seperti musyawarah batin jurai, dan ritual-ritual khusus. Meskipun anak yang dikampinya kelak mampu mendirikan rumah sendiri berapapun jumlahnya, seeperti apapun mewahnya, ia tetap harus tinggal dan menjaga rumah peninggalan oang tuanya itu (harta pusaka) sehingga pola menetapnya cenderung matrilokal.

Harta lain seperti kebun karet atau huma ladang, tetap diberikan kepada anak kampinya sebagai bekal untuk hidup, dan menghidupi semua anggota keluarganya termasuk saudara-saudaranya yang belum mandiri. Namun kebun atau ladang sifatnya tidak masif dipertahankan, kebun atau ladang masih diperbolehkan dijual jika keadaannya sangat mendesak. Pada masyarakat Lematang dikenal juga adanya istilah harta budal. Harta budal adalah harta peninggalan orang tua yang belum diwasiatkan secara khusus kepada ahli warisnya. Dalam keadaan demikian, harta itu akan menjadi milik bersama (budal) para ahli waris. Harta budal ini sifatnya tidak bisa dijual oleh salah satu ahli waris. Apabila akan menjualnya, harus ada musyawarah jurai yang dipimpin tetue batin, dan ada kesepakatan bersama antar ahli waris.

Harta budal ini biasanya berupa rumah orang tua, pekarangan kosong, sawah, atau sebidang kebun. Tapi umumnya adalah rumah orang tua dan kebun. Biasanya orang tua yang sengaja meninggalkan harta budal bertujuan agar aset tersebut tidak dijual, dan dipertahankan secara turun-temurun, seperti yang terjadi pada adat tunggu tubang di Semendo. Terlebih lagi peninggalan puyang (nenek moyang) maka harus terus dipertahankan, tidak boleh dijual. Dalam sistem kampi, rumah atau harta yang diberikan pada anak kampinya kebanyakan bukan harta budal, melainkan sudah dihibahkan melalui surat wasiat maupun kesepakatan dan musyawa rah jurai yang disaksikan oleh seluruh anggota jurai. Harta yang demikian tidak dapat lagi diganggu gugat oleh anggota jurai yang lain.

\section{Stigma Kawin Kampi}

stilah kampi menjadi sesuatu yang tabu diucapkan bagi masyarakat Lematang, apalagi diucapkan kepada orang yang benar-benar mengalaminya. Masyarakat Lematang amat menjaga sistem patrilinial dan patriarkat mereka. Istilah kawin kampi bagi masyarakat Lematang adalah sesuatu yang sebisa mungkin tidak dilakukan, karena akan melemahkan patriarki mereka.

Berdasarkan temuan di lapangan, masyarakat Lematang menganggap tradisi kampi tidak cocok dilakukan pada komunitas mereka yang menarik garis keturunan dari anak laki-laki. Para laki-laki Lematang juga menanggap praktik kawin kampi akan membuat dirinya seperti kerbau dicucuk hidung pepatah lokal menyebut "macam kebau dicucuk buling" maknanya adalah kemanapun istrinya melangkah dan bergerak, si laki-laki akan selalu mengikuti nya tanpa kuasa untuk membantahnya. Kondisi ini tentu sangat berkaitan erat dengan masalah ekonomi, baik ekonomi pihak perempuan maupun kondisi ekonomi pihak laki-lakinya. Perkawinan kampi yang menempatkan laki-laki secara subordinat disebabkan kemiskinan. Pandangan masya rakat menganggap jika laki-laki yang bersedia dikampi adalah laki-laki yang sangat miskin sehingga tidak mampu lagi untuk membayar mahar.

Beberapa informan yang saya temui mereka mengatakan bahwa orang-orang yang melakukan kampi akan merasa dirinya hina, tersisih, dan tertekan, karena masya rakat menilai kawin kampi adalah serendahrendahnya perkawinan. Bagi masyarakat Lematang, meski dirinya hidup dalam 
kemiskinan namun akan tetap berusaha agar semua anak laki-lakinya jangan ada yang kampi, kemiskinan bagi mereka bukan suatu alasan untuk menyerah pada keadaan. Perkawinan kampi menurutnya adalah seburuk-buruknya perkawinan di Lematang, bahkan jika dibanding kawin lari masih lebih terhormat kawin lari, karena kawin lari dilakukan secara patrilokal.

Para informan mengatakan jika sampai ada salah satu dari anak laki-lakinya yang tekampi, maka dirinya akan menyesal seumur hidup dan merasa bersalah karena tidak memiliki tanggungjawab terhadap anak-anaknya. Mereka juga menambahkan jika dirinya sampai membiarkan kawin kampi terjadi pada anaknya, maka anaknya tersebut akan menanggung beban moril sepanjang hidupnya, ia akan merasa dirinya terbuang dari keluarganya sendiri karena harus terputus dari garis keturunan agnatiknya.

Stigma negatif masyarakat terkait kawin kampi sangat erat kaitannya dengan budaya patriarki di Lematang. Dalam kebudayaan patriarki ini, perempuan diang gap berperan domestik dalam urusan rumah tangga, sedangkan laki-laki berperan publik. Padahal, perempuan sama halnya dengan laki-laki, bisa melakukan apasaja di luar peran domestiknya. Peran perempuan yang domestik inilah oleh prinsip maskulinitas telah menempatkan perempuan di bawah laki-laki (Harum, 2012:1). Kondisi demikian diinternalisasi oleh komunitas menjadi se buah kebiasaan, pada akhirnya segala perilaku yang menempatkan laki-laki dalam posisi subordinat akan dianggap sebagai perilaku yang tabu.

\section{Kampi Sebagai Mekanisme Mempertahankan Keturunan Agnatik}

$\mathrm{S}$ ebagai sebuah praktik sosial, kawin kampi dikonstruksi oleh kolektif sebagai upaya mempertahankan ga ris patrilinial mereka. Kampi dilegitimasi sebagai bagian dari sistem organisasi sosial Lematang. Kawin kampi biasanya dilakukan oleh laki-laki yang tidak memiliki keturunan laki-laki sehingga anak perempuan statusnya dijadikan sebagai anak laki-laki untuk meneruskan garis keturunannya, sehingga pola perkawinannya menjadi matrilokal. Oleh sebab itu, kampi dianggap bertentangan dengan prinsip patrilinial dan patriarki di Lematang, karena sistem perkawinan yang ideal adalah patrilokal. Namun, kampi tetap dipertahankan eksistensinya di dalam struktur organisasi sosial mereka.

Kampi di satu sisi dilegitimasi sebagai mekanisme untuk mengatasi masa lah hilangnya garis keturunan, di sisi lain kampi dianggap sebagai praktik yang menodai sistem patrilinial dan patriarki. Hal ini karena kawin kampi menghendaki perubahan afiliasi bagi laki-laki dan memosisikan laki-laki menjadi subordinat di bawah ranah kekuasaan perempuan. Perubahan afiliasi tersebut mengakibatkan terputusnya garis patrilinial laki-laki di keluarganya sendiri. Pola semacam ini dianggap tidak ideal dalam pandangan kolektif.

Perkawinan matrilokal terjadi karena hutang mahar bagi laki-laki dalam sistem patrilinialnya. Hutang mahar ini akibat dari ketidakmampuan laki-laki dalam menunai kan kewajibannya sebagai aktor sentral dalam sistem patrilinial. Pada kondisi lain, alasan keluarga perempuan yang melaku kan kampi karena tidak memiliki anak lakilaki sebagai penerus garis keturunan, sehingga mengubah status anak perempu annya sebagai anak laki-laki untuk meneruskan keturunannya. Bagi orang Lematang yang tidak memiliki anak laki-laki, akan menjadi aib karena tidak mampu mempertahankan garis patrilinialnya. Jika dibiarkan maka akan dianggap sebagai tindakan melanggar tabu. Sedangkan bagi keluarga laki-laki, kawin kampi akan menjadi tindakan yang dihindari karena terputusnya garis keturunan, oleh karena nya keluarga laki-laki yang akan menjalani kampi harus memiliki anak laki-laki lebih dari satu orang.

Di sisi lain, biasanya keluarga lakilaki yang menjalani kampi berada pada kondisi ketidakmampuan membayar mahar

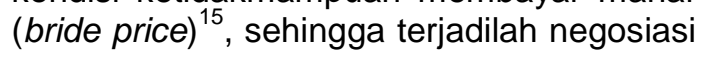
antara kedua pihak untuk melaksanakan perkawinan matrilokal. Kampi merupakan kesepakatan dari negosiasi putusnya garis patrilinial di kedua belah pihak, serta kondisi kemiskinan laki-laki dan ketidakmampuan membayar mahar. Konsekuensinya, laki-laki harus berafiliasi ke dalam garis agnatik

15 Bride Price dalam istilah lokal adalah uang jemputan (biaye antar-antaran)

101 | P a g e 
istrinya, dan anak-anaknya harus berafiliasi ke dalam garis keturunan ibunya (matri linial). Kondisi demikian menyebabkan kebingungan kategori bagi kolektif, di satu sisi dimaknai kolektif sebagai tindakan mematuhi tabu atau solusi bagi terputusnya garis patrilinial, di sisi lain dianggap melanggar tabu karena memutuskan garis patrilinial sebagian yang lain.

Pola Afiliasi pada masyarakat Lematang menganut pola patrilinial. Namun aturan-aturan dalam pola perkawinan matrilokal (kampi) mengakibatkan perge seran pada pola afiliasi di Lematang menjadi matrilinial sehingga disebut ambilinial. Melalui pergeseran pola afiliasi ini ternyata turut juga memengaruhi relasi kekuasaan pada keluarga yang mempraktik kan kampi tersebut. Pola matrilokal yang mengedepankan istri sebagai peran utama dalam mengakses sumber-sumber ekonomi mengakibatkan relasi kekuasaan yang bersifat matriarki menjadi dominan. Pola relasi matriarkat ini menempatkan laki-laki pada posisi subordinasi. Pola perkawinan matrilokal dikonstruksi oleh kolektif sebagai satu mekanisme untuk mendukung langgengnya sistem patrilinial Lematang. Kawin kampi dilegitimasi sebagai solusi bagi terputusnya garis keturunan patrilinial.

Pada kenyataannya, kawin kampi dimaknai sebagai sebuah sistem yang merusak institusi patriarki di Lematang. Kontradiksi terhadap fenomena ini terlihat dari stigma masyarakat terhadap pelaku kampi yang dianggap telah melakukan sebuah praktik abnormal. Bagi masyarakat Lematang yang menjunjung patriarki posisi laki-laki adalah superior dalam segala bidang kehidupan, terutama sebagai penerus garis patrilinial dan pengakses sumber daya. Oleh sebab itu, bagi keluarga yang tidak memiliki anak laki-laki maka garis kerabatnya menjadi terputus. Untuk mempertahankan dan membangun institusi patrilinial itu, keluarga yang tidak memiliki anak laki-laki diperbolehkan melakukan perkawinan kampi yaitu mengambil salah satu anak perempuannya untuk meneruskan garis patrilinialnya. Kawin kampi ini akan berlaku kepada generasi selanjutnya jika belum juga memiliki keturunan laki-laki.

Konsekuensi dari kampi adalah berafiliasinya laki-laki tersebut ke dalam garis kerabat perempuan. Kawin kampi juga menuntut kesiapan perempuan sebagai aktor yang akan mengambilalih peran, fungsi, dan posisi laki-laki beserta segala tanggungjawab yang dilekatkan kepadanya dalam sistem organisasi sosial. Sebaliknya pada laki-laki yang tekampi, ia akan berkedudukan sebagai tamu di keluarga perempuan yang harus dihormati dan dihargai. Tetapi pada kenyataannya, lakilaki kampi justru memeroleh stigma buruk dan mengalami ketertekanan psikis karena berlakunya otoritas matriarki. Pengalaman buruk demikian ini mengakibatkan kawin kampi menjadi tabu dalam sistem organisasi sosial mereka. Kawin kampi dianggap menjadi faktor utama berubahnya institusi patrilinial Lematang menjadi sistem ambilinial yang di dalamnya memberlakukan sistem matrilinial untuk beberapa generasi. Perubahan pola afiliasi ini juga mengakibatkan pemberlakuan residensi matrilokal dan otoritas matriarkat.

\section{Daftar Pustaka}


Asosiasi Emiten Indonesia. 2014. Kamus Online Pasar Modal. Jakarta: Indonesian Public Listed Companies Association

Ember, Carol R. and Melvin Ember. 2007. Anthropology Twelfth Edition. New Jersey: Pearson Practice Hall

Firth, Raymond. 1963. We The Tikopia. Boston: Beacon Press.

Freud, Sigmund. 2001. Totem and Taboo; Some Points of Agreement between the Mental Lives of Savages and Neurotics. London: Routledge Classics

Gunawan, Istutiah, 2000. Hierarchy and Balance; A Study of Wanoaka Sosial Organization, Canberra: The Australian National University Press.

Harum, Diah Meutia. 2012. Internalisasi Ideology Gender dan Dominasi Maskulin pada Tokoh Sassy dalam Novel Tea for Two . Jakarta: Universitas Indonesia

Hapsari, Octaviani Eka. 2001. Disonansi Kognitif pada Orang Tua yang Anaknya Melakukan Kawin Lari, Studi Kasus Kawin Lari Antara Etnis Pribumi dengan Etnis non Pribumi di Palembang. Jakarta: Universitas Indonesia

Haviland, William R. 1985. Anthropology 4th Edition, London: CBS College Publishing.

Hefni, Muhammad. 2012, Perempuan Madura di Antara Pola Residensi Matrilokal dan Kekuasaan Patriarkat. dalam Jurnal Sosial dan Budaya Keislaman/Vol 20, No 2 th. 2012

Koentjaraningrat, 1980. Sejarah Teori Antropologi, Jakarta: UI-Press

Murdock, George Peter. 1949. Sosial Structure, New York: The Macmillan Company.

Levi Strauss, Claude. 1972. Structural Anthropologi. London: Penguin.

Malinowski, Bronislaw. 1922. Argonauts of the Western Pacific. New York: EP. Dutton

Radcliffe-Brown, A.R. 1952. Structure and Function in Primitive Society. London: Routledge

Rudyansjah, Tony. 2015. Emile Durkheim; Pemikiran Utama dan Percabangannya ke Radcliffe Brown, Fortes, Levi Strauss, Turner, dan Holbraad. Jakarta: Kompas Media Nusantara.

Saifuddin, Achmad Fedyani. 2015. Logika Antropologi. Jakarta: Prenada Media Group

Turner, Victor. 1969. The Ritual Process; Structure and Anti-Structure. New York: Cornell University Press

Valeri, Valerio. 2000. The Forest of Taboos; Morality, Hunting, and Identity among the Huaulu of the Moluccas. Wisconsin: The University of Wisconsin Press 2001. Fragment From Forests and Libraries. North Carolina: Carolina Academic Press

Wouden, F.A.E Van. 1968. Sosiale Struucturtypen in de Groote Oost. 1935. Leiden: KITLV. (Types of Sosial Structure in Eastern Indonesia. Terj. R. Needham (terbitan pertama dalam Bahasa Inggris 1935). The Hague: Martinus Nijhoff). (Klan, Mitos, dan Kekuasaan; Struktur Sosial Indonesia Bagian Timur terj. Anggota $I K A P I$, (terbitan pertama dalam bahasa Indonesia 1985) Jakarta: graffiti Pers. 